\title{
Upaya Sekolah dan Keterlibatan Orang Tua dalam Pembelajaran di Masa Pandemi Covid-19
}

\author{
I Putu Ayub Darmawan ${ }^{1}$, Patri Alinda Nalle ${ }^{2}$, Magdalena ${ }^{3}$, Marderina ${ }^{4}$, Yustina Julita ${ }^{5}$ \\ 1,2,3,4,5 Sekolah Tinggi Teologi Simpson Ungaran \\ Email: putuayub.simpson@gmail.com
}

\begin{abstract}
Abstrak
Pandemi covid-19 telah memaksa pembelajaran dilaksanakan dengan cara berbeda. Siswa harus belajar dari rumah, sementara Sekolah dan guru harus menyelenggarakan pembelajaran yang efektif. Demikian pula orang tua harus berperan aktif melaksanakan pembelajaran dari rumah. Untuk itu, penulis melakukan penelitian terdahap upaya sekolah dan keterlibatan orang tua dalam pembelajaran di masa pandemi covid-19. Penelitian ini menggunakan pendekatan kualitatif dengan mengumpulkan data melalui wawancara. Hasil penelitian menunjukkan beberapa upaya TK Isa Almasih dalam mewujudkan kegiatan belajar pada masa pandemi covid-19 adalah 1) Merancang pembelajaran yang menstimulus siswa belajar sesuai dengan tema belajar dan efisien secara ekonomi; 2) Bekerjasama dengan orang tua murid dengan mengadakan pertemuan terbatas membahas perkembangan siswa; 3) Menggunakan sosial media untuk menyampaikan informasi yang berkaitan dengan bahan ajar dan pemberitahuan hasil belajar murid. Sementara bentuk keterlibatan orang tua dalam pembelajaran dari rumah yaitu 1) Menjadi penuntun anak dalam belajar dari rumah; 2) Orang tua berperan menjadi operator.
\end{abstract}

Kata Kunci: Peran Orang Tua, Pembelajaran Masa Pandemi, Taman Kanak-Kanak

\section{School Efforts and Parental Involvement in Learning During the Covid-19 Pandemic}

\author{
I Putu Ayub Darmawan ${ }^{1}$, Patri Alinda Nalle ${ }^{2}$, Magdalena $^{3}$, Marderina $^{4}$, Yustina Julita ${ }^{5}$ \\ 1,2,3,4,5 Sekolah Tinggi Teologi Simpson Ungaran \\ Email: putuayub.simpson@gmail.com
}

\begin{abstract}
The Covid-19 pandemic has forced learning to be carried out in a different way. Students must learn from home, while schools and teachers must organize effective learning. Likewise, parents must play an active role in carrying out learning from home. For this reason, the authors conducted research on school efforts and the involvement of parents in learning during the Covid-19 pandemic. This study uses a qualitative approach by collecting data through interviews. The results showed that the efforts of Isa Almasih Kindergarten to realize learning activities during the Covid-19 pandemic were 1) Designing learning that stimulates students to learn according to the learning theme and is economically efficient; 2) Collaborating with the parents by holding a limited meeting to discuss student development; 3) Using social media to convey information related to teaching materials and notification of student learning outcomes. While the forms of parental involvement in learning from home are 1) Being a guide for children in learning from home; 2) Parents act as operators.
\end{abstract}

Keywords: Role of Parents, Learning during the Pandemic, Kindergarten 


\section{PENDAHULUAN}

Pandemi covid-19 berdampak secara global, dimana seluruh dunia merasakan wabah covid-19 (Abidah, Hidaayatullaah, Simamora, Fehabutar, \& Mutakinati, 2020; Onyema et al., 2020). Dampak yang terjadi bukan hanya mempengaruhi perekonomian Negara, melainkan juga dibidang pendidikan. Pemerintah pusat maupun daerah memberikan kebijakan agar pelaksanaan pembelajaran dilakukan dari rumah. Karena pembelajaran tidak mungkin dilakukan di sekolah, sekolah-sekolah kemudian diharuskan berinovasi agar pembelajaran dapat tetap berjalan walau terdapat berbagai keterbatasan. Handayani (2020, p. 15) menjelaskan bahwa pandemi covid-19 telah menyebabkan terjadinya perubahan kebiasaan manusia, temasuk juga dalam pendidikan. Kegiatan belajar kemudian berpindah dari sekolah ke rumah, dan orang tua kemudian mengambil peran yang lebih banyak dalam proses pembelajaran. Walau demikian, sekolah terus berupaya untuk menghadirkan pembelajaran yang inovatif, kreatif, dan variatif sehingga pembelajaran tetap dapat laksanakan dengan efektif.

Purwanto et al. (Purwanto et al., 2020), menjelaskan bahwa akibat dari adanya pandemi covid-19 yang sangat dirasakan oleh para siswa adalah dengan melakukan pembalajaran daring (online), namun alat- alat teknologi komunikasi dan informasi yang diperlukan siswa di rumah sangat terbatas. Dengan kondisi bahwa anak harus mengikuti proses pembelajaran dari rumah, maka orang tua diminta berpartisifasi secara aktif dalam menuntun anak-anaknya guna dapat mengikuti proses pembelajaran yang diberikan sekolah. Purwanto et al. (Purwanto et al., 2020), maupun Karnawati dan Mardiharto (2020, p. 14) mengungkapkan pembelajaran dari rumah membuat terjadinya partisipasi orang tua dalam berbagai bidang untuk menyukseskan pembelajaran. Beberapa penelitian terdahulu seperti penelitian Nurjanah (2007), Lilawati (2020) menemukan bahwa orang tua berperan sebagai pembimbing dan pendamping anak dalam belajar daring. Lilawati (2020) dan Hayati (2020) juga menemukan peran lain orang tua bagi anak selama masa pademi covid-19 adalah sebagai motivator sehingga memicu motivasi anak dalam belajar. Selain seperti temuan penelitian di atas, penelitian Ekayanti dan Puspawati (2020) juga menemukan bahwa orang tua, khususnya ibu berperan menjadi fasilitator dan sebagai director dalam pembejalaran daring. Penelitian Cahyati dan Kusumah (2020) justru menemukan bahwa selama pembelajaran daring, para orang tua dapat memahami tingkat tumbuh kembang anakanaknya sehingga dapat membantu sekolah 
mencapai tujuan pendidikan. Secara keseluruhan selama pandemi Covid-19 orang tua memang memiliki peranan penting. Menurut Emiyati Nainupu dan Emiyati (2020) orang tua memiliki peranan penting dalam keberhasilan anak. Dari beberapa penelitian tersebut, tampak jika ada partisipasi orang tua untuk mewujudkan pembelajaran yang baik bagi anak-anak mereka.

Kondisi di atas juga terdampak pada TK Isa Almasih, Pangkalan Bun Kalimantan Tengah. Taman kanak-kanak ini juga harus melakukan pembelajaran secara daring agar anak-anak tetap dapat mengikuti proses pendidikan dengan baik. Kemudian orang tua juga harus melakukan bimbingan terhadap anak-anak dalam mengikuti proses pembelajaran di rumah. Secara teoritis, orang tua memang memiliki tanggung jawab untuk mendidik anak-anak (Mary, 2020), terutama dalam kondisi darurat pandemi covid-19. Dari data awal yang dikumpulkan oleh peneliti, tampak ada upaya sekolah dan peran serta orang tua untuk mewujudkan terjadinya pembelajaran yang menarik dimasa pandemi covid-19. Hanya secara spesifik bagaimana upaya tersebut dilakukan dan bagaimana peran orang tua dalam pembelajaran perlu didalami sehingga dapat memberi kontribusi secara keilmuan.
Rumusan masalah dalam penelitian ini adalah penulis ingin menjelaskan bagaimana upaya sekolah dan partisipasi orang tua melaksanakan kegiatan belajar pada masa pandemi covid-19? Melalui observasi ini penulis memiliki tujuan penulisan yaitu untuk mendeskripsikan upaya sekolah melaksanakan kegiatan belajar pada masa pandemi covid-19.

\section{METODE}

Pendekatan penelitian ini menggunakan pendekatan penelitian dengan menggunakan penelitian kualitatif. Untuk mendapatkan informasi tentang upaya sekolah dalam melaksanakan proses pembelajaran terkait dengan adanya covid19 dan proses pembelajaran yang dilakukan secara daring penulis melakukan wawancara kepada pihak Kepala Sekolah dan guru-guru. Sementara untuk mengetahui peran serta orang tua, penulis melakukan wawancara kepada para orang tua sehingga menemukan apa saja yang mereka lakukan untuk mendukung pembelajaran anak-anak.

Hasil data wawancara kemudian penulis klasifikasikan dan disajikan secara deskriptif. Hasil wawancara tidak disajikan berdasarkan pertanyaan wawancara ataupun sumber data melainkan dilakukan sintesa sehingga hasil penelitian disajikan secara deskriptif naratif. 


\section{HASIL DAN PEMBAHASAN}

Upaya Sekolah Melaksanakan

Pembelajaran di Tengah Pandemi Covid-19

Merancang Pembelajaran

Pada masa pandemi covid-19 ini mengakibatkan proses belajar mengajar di dunia pendidikan menjadi terhambat. Oleh sebab itu guru-guru harus lebih kreatif lagi, agar proses pembelajaran tidak terhambat dengan kondisi dan situasi yang terjadi. Banyak pembelajaran menggunakan sistem daring, sehingga tidak membatasi siswa untuk terus mengembangkan potensi diri baik secara akademis dan non akademis (Septikasari \& Ayriza, 2018, p. 47).

Dalam penelitian yang penulis lakukan di TK Isa Almasih, upaya yang dilakukan oleh Kepala Sekolah dan guru adalah merancang pembelajaran kreatif, inovatif, variatif dan tentunya edukatif yang dapat dilakukan dengan bantuan orang tua. Kepala Sekolah bersama Guru-guru merancang dan kemudian memberikan materi pembelajaran yang menstimulus siswa untuk mengikuti pembelajaran berdasarkan tema belajar yang telah di programkan. Pembelajaran pengenalan lingkungan yang biasa dilakukan secara praktik kini menjadi berbeda. Guru memanfaatkan media audio visual berupa gambar air dan udara untuk menjadi panduan bagi siswa dalam proses pembelajaran. Siswa dapat berkarya dalam gambar berdasarkan audio visual yang ada.
Selain itu, pembelajaran tentang udara dijelaskan dengan memanfaatkan bendabenda dan penjelasan kegunaan udara pada benda. Contohnya: udara pada roda transportasi dan benda-benda lain yang berkaitan dengan udara. Praktik pemanfaatan air juga dilakukan secara langsung oleh siswa dengan melakukan kegiatan yang positif di rumah dan tentunya berkaitan dengan air. Setiap kegiatan praktik yang dilakukan oleh siswa juga melibatkan orang tua dalam membimbing. Hal ini sejalan dengan penelitian Efendi (2020) bahwa ada peran orang tua dalam pembelajaran yang berkaitan dengan lingkungan. Selain itu dalam pembelajaran di rumah guru juga memberikan arahan kepada siswa pentingnya menjaga protokol kesehatan pada masa pandemi covid-19.

Selain mengusahakan kelangsungan belajar di tengah covid-19, guru TK Isa Almasih juga memikirkan kedaan ekonomi orang tua, sehingga tugas-tugas yang diberikan pun tidak begitu sulit atau menghabiskan dana yang banyak dan tidak membebani orang tua. Guru dan orang tua bekerjasama secara efisien untuk tetap mewujudkan pembelajaran yang efektif di tengah situasi pandemi yang juga berdampak pada sektor ekonomi. Sekolah mencoba merancang pembelajaran yang tidak menggunakan dana besar seperti dengan memanfaatkan bahan sederhana 
yang tersedia disekitar dan juga ramah lingkungan.

\section{Bekerjasama Dengan Orang Tua Murid}

Guru memiliki peran penting dalam mewujudkan situasi belajar mengajar yang menarik bagi siswa. Penanganan kelas yang baik menjadikan suasana tenang dan teratur selama pembelajaran berlangsung (Sanjaya, 2006, p. 24). Dengan adanya dampak covid-19 siswa diwajibkan untuk mengikuti proses pembalajaran secara daring. Oleh sebab itu pentingnya keterlibatan orang tua untuk mengarahkan anak-anaknya dalam kegiatan pembelajaran. Kerjasama antara pihak sekolah dengan orang tua anak merupakan hal yang sangat diperlukan agar tujuan belajar mengajar dapat terealisasikan.

Bentuk kerjasama yang dilakukan orang tua dan sekolah adalah dengan mengadakan pertemuan terbatas dari pihak orang tua dan guru. Dalam pertemuan tersebut, orang tua dan guru berbagi informasi perkembangan siswa dalam belajar dari rumah. Selain itu, orang tua kemudian menjadi mediator penyajian bahan ajar dari guru kepada siswa. Berkaitan dengan hal ini guru harus terlebih dahulu menjelaskan pada orang tua apa dan bagaimana materi dipelajari atau dikerjakan. Tindakan ini harus dilakukan oleh guru sebab sangat sulit jika seluruh pembelajaran dilaksanakan secara daring bagi anak-anak usia dini. Hal ini sejalan dengan penelitian Ekayanti dan Puspawati (2020), dimana orang tua menjadi fasilitator dan director dalam pembelajaran.

Guru harus bekerjasama dengan orang tua sebab orang tua dapat memberikan pengawasan dan pendampingan, bahkan menciptakan lingkungan belajar yang baik bagi anaknya. $\mathrm{Di}$ tengah kondisi pembatasan sosial, guru harus membatasi diri berinteraksi langsung dengan siswa. Dalam hal ini, orang tualah yang dapat mengambil peran memberikan pengawasan dan pendampingan, bahkan menciptakan lingkungan belajar yang baik. Hal ini memungkinkan terjadi karena keluarga adalah kelompok sosial yang dapat menjadi tempat orang tua mengajar anaknya dan memberikan penguatan secara internal (Subarto, 2017).

\section{Menggunakan Sosial Media}

Pelaksanaan pembelajaran membutuhkan media agar pesan dapat disampaikan (Hutapea, 2020; Tafonao, 2018). Sarana pembelajaran yang dimanfaatkan dalam proses pembelajaran di rumah ialah sosial media. Ada berbagai sosial media yang difungsikan oleh masyarakat, salah satu nya ialah youtube. Namun dalam penggunaan sosial media ada batasan tertentu yang dapat memiliki akun 
di sosial media yaitu minimal berumur 16 tahun ke atas (Harper, 2020; "WhatsApp," 2018). Oleh sebab itu, anak di bawah umur (TK) perlunya bimbingan dari para orang tua dalam mengikuti proses pembelajaran di rumah karena yang memiliki akun sosial media ialah para orang tua. Dari hal ini dapat terlihat adanya kerjasama dari para orang tua anak dan guru, sehingga pelaksanaan pembelajaran di rumah dapat berjalan dengan baik. Memberikan pengawasan dan pembatasan bagi anak merupakan tugas orang tua selama kegiatan belajar di rumah.

Mencermati perkembangan anak serta ketentuan minimal penggunaan media sosial, maka anak usia dini belum diizinkan untuk menggunakan gadget. Tetapi selama masa pandemi covid-19, guru memanfaatkan gadget, whatsapp untuk menyampaikan materi pembelajaran. Agar pemanfaatan media sosial dalam masa belajar dari rumah tetap aman bagi siswa, diperlukan kerjasama orang tua dalam proses pembelajaran di rumah dengan memberikan pengawasan, dan pembatasan (Rianingtias, 2017, p. 15). Mengacu pada penelitian Ritonga (2020), untuk memaksimalkan peran orang tua, sekolah perlu memiliki pemahaman batasan keterlibatan orang tua selain itu perlu membangun komunikasi yang baik.
Guru TK Isa Almasih memanfaatkan sosial media selama kegiatan belajar dari rumah berlangsung. Sosial media dimanfaatkan sebagai penyampaian materi kepada murid dan pengumpulan tugastugas siswa menjadi bagian dari orang tua untuk memberikan kepada guru yang bersangkutan dengan mata pelajaran setiap harinya. Kegunaan sosial media oleh wali kelas yaitu untuk pembuatan group yang terdiri dari para orang tua siswa dan wali kelas. TK Isa Almasih memberikan materi pembelajaran secara langsung (orang tua mengambil dan mengembalikan tugas ke sekolah dengan tetap mengikuti PROKES) dan secara tidak langsung (mengirim materi pembelajaran melalui whatsapp) dan cara belajar yang lengkap sehingga memudahkan orang tua mendampingi siswa. Dalam hal ini pentingnya partisipasi orang tua dalam memantau perkembangan anak dalam kegiatan pembelajaran di rumah. Sehingga pendidikan anak tidak sepenuhnya menjadi tanggung jawab guru.

Dengan adanya peran aktif orang tua dalam proses pembimbingan bagi anak, memicu para orang tua untuk ikut belajar kembali. Belajar kembali dalam hal ini lebih mengarah kepada tugas dan tanggung jawab orang tua dalam memberikan didikan yang sepadan dengan ajaran agama.

Dalam proses belajar dari rumah, orang tua murid diminta untuk memvideokan 
proses belajar anak, dan juga foto-foto tugas dan kegiatan murid. Namun penggunaan media sosial tidak selamanya berjalan dengan lancar karena adanya hambatan yang harus dipikirkan para guru, materi apa yang hendak diberikan dalam situasi wabah covid-19? Sedangkan orang tua siswa terbatas dalam memahami makna materi pembelajaran dengan baik. Berdasarkan surat Mendikbud Nomor 4 Tahun 2020, kegiatan pembelajaran yang di lakukan dari rumah memberikan makna tersendiri bagi siswa untuk tidak memfokuskan diri kepada pencapaian kurikulum, namun dapat difokuskan pada pendidikan kemampuan (skill). Dengan demikian para guru TK Isa Almasih tidak hanya berfokus kepada bahan ajar melainkan dapat memberikan tugas dengan berbagai variasi. Pendidikan kemampuan yang memberi pengalaman sangat bernilai bagi para siswa untuk dapat mengembangkan diri, salah satu nya ialah dalam pembuatan kerajinan tangan.

\section{Bentuk Keterlibatan Orang Tua}

Berdasarkan hasil wawancara yang penulis lakukan kepada kepala sekolah, guru, maupun orang tua ada dua bentuk keterlibatan orang tua dalam kegiatan belajar anak di rumah dalam masa pandemi covid-19, yaitu:

\section{Menuntun Anak dalam Belajar Dari Rumah}

Peran pertama yang harus dilakukan adalah menuntun anak untuk mengerjakan bahan pelajaran yang telah disediakan oleh guru-guru yang bersangkutan. Selain terlibat dalam pengambilan materi pelajaran, orang tua juga berperan dalam membantu guru-guru dalam menjelaskan kembali apa yang telah disampaikan guru pada orang tua. Dengan demikian orang tua melakukan tugas sebagai penuntun pesertadidik dalam mengerjakan materi pembelajaran dari sekolah. Contohnya orang tua membantu dan menuntun anak untuk mengunting, mewarnai, mengambar, dII.

Peran ini searah dengan penelitian yang dilakukan oleh Nurjanah (2007), Diana (2019), Lilawati (2020), Lilawati (2020), Hayati (2020), Ekayanti dan Puspawati (2020). Orang tua dalam peran ini memberikan bimbingan dan pendampingan pada siswa sehingga mereka dapat mengikuti proses pembelajaran sebagaimana telah direncanakan oleh Sekolah. Karena anak-anak kesulitan untuk mengetahui susunan materi pembelajaran secara terstruktur maka dalam hal ini orang tua yang memberikan tuntunan agar siswa dapat mengikuti pembelajaran dengan baik. Subarto (2017) mengungkapkan jika kondisi pandemi Covid-19 merupakan momentum bagi orang tua untuk mengembangkan 
kemampuan belajar anak. Jadi, di masa pandemi peran orang tua bukan sematamata beban, melainkan peluang terlibat memberikan bimbingan pada anak.

\section{Orang Tua Menjadi Operator}

Dengan pembalajaran dari rumah, orang tua menjadi penghubung antara anak dengan guru. Orang tua membantu anak untuk mengambil media pembelajaran atau bahan belajar yang sudah disediakan oleh sekolah untuk dibawa kerumah agar dikerjakan oleh anak. Guru-guru TK Isa Almasih menyampaikan informasi pada orang tua melalui WA grup sekolah untuk mengambil media pembelajaran atau bahan belajar yang disiapkan oleh sekolah. Kemudian orang tua juga mengembalikan atau mengumpulkan tugas yang sudah dikerjakan oleh anak-anak kepada guruguru. Selain mengambil media pembelajaran atau bahan ajar, guru-guru memberikan penjelasan kepada orang tua mengenai langkah-langkah dalam mengerjakan tugas yang diberikan dari sekolah sehingga orang tua dapat melakukan pendampingan dan pengawasan terhadap proses belajar. Selain komunikasi langsung dengan bertemu di sekolah, guru dan orang tua berkomunikasi memanfaatkan media sosial sehingga dapat menolong anak-anak mereka dalam belajar.
Selain menjadi penghubung dalam hal komunikasi, orang tua juga menolong anak dalam menggunakan sosial media yang digunakan sebagai media penghubung pembelajaran. Dalam pembelajaran daring, media sosial sangat penting perannya sebagai media komunikasi. Tetapi karena anak-anak masih memerlukan pendampingan, orang tua memiliki peran yang penting dalam menyediakan sarana seperti handphone maupun komputer dan melakukan pendampingan dalam menggunakannya. Dalam pembelajaran dari rumah, handphone adalah media yang paling sering digunakan, sehingga orang tua berperan dalam memberikan bimbingan dalam menggunakan media tersebut. Orang tua juga terlibat dalam mendokumentasikan kegiatan-kegiatan yang dilakukan oleh peserta didik selama mengerjakan tugas dari sekolah, kemudian mengirimkan dokumentasi lewat foto, video melalui grup Whatshap kepada guru sebagai bukti bahwa peserta didik sudah melakukan pembelajaran sebagaimana telah direncanakan oleh TK ISA Almasih.

Dari penelitian ini tampak jika orang tua tidak hanya berperan sebagai guru, pembimbing, dan motivator sebagaimana tampak dalam penelitian lainnya. Penelitian Nurjanah (2007), Lilawati (2020), Lilawati (2020), dan Hayati (2020) menunjukkan jika orang tua berperan sebagai guru, 
pembimbing, dan motivator. Dari hasil penelitian tampak jika dalam proses pembelajaran di TK Isa Almasih, ada peran berbeda yaitu sebagai operator. Peran ini hamper sama dengan apa ditemukan oleh Ekayanti dan Puspawati (2020) yang mana orang tua menjadi fasilitator bagi siswa. Tetapi dalam penelitian ini menemukan jika mereka tidak hanya sekedar menjadi fasilitator, melainkan benar-benar menjadi operator antara guru dan siswa. Apa yang disampaikan guru pada siswa disampaikan melalui orang tua. Sebagaimana hasil wawancara pada Kepala Sekolah tampak jika Kepala Sekolah membimbing guru-guru dalam merencanakan pembelajaran dan kemuadian orang tua harus memberikan penjelasan materi kepada orang tua, setelah itu baru orang tua menyampaikan materi yang sama kepada anak.

Cara yang demikian tampaknya lebih efisien dibandingkan melakasanakan pembelajaran secara daring. Hal ini sejalan dengan temuan penelitian Purwanto et al. (Purwanto et al., 2020) bahwa selama pandemi Covid-19 pembelajaran daring menambah beban biaya orang tua. Oleh sebab itu dengan pola yang digunakan oleh pihak TK Isa Almasih dan peran orang tua biaya untuk paket internet dapat ditekan. Tetapi membutuhkan komitmen orang tua untuk mewujudkan pembelajaran yan baik dan berkualitas.

\section{SIMPULAN DAN SARAN}

Pandemi covid-19 telah mendunia dan membawa dampak yang sangat besar bagi dunia. Sehingga pemerintah harus mengambil kebijakan untuk melakukan sosial distancing agar penyebaran covid-19 dapat diatasi. Dalam bidang pendidikan pemerintah harus mengambil kebijakan untuk menyelenggarakan pendidikan secara daring maupun bekerjasama dengan orang tua murid. Seperti halnya dengan TK Isa Almasih, Pangkalan Bun, Kalimantan Tengah tetap melaksanakan proses pembelajaran dengan bantuan orang tua untuk membimbing anak agar tetap mengikuti proses pembelajaran dengan baik.

Upaya TK Isa Almasih dalam proses belajar mengajar di tengah pandemi covid19 adalah 1) Merancang pembelajaran yang menstimulus siswa untuk mengikuti pembelajaran sesuai dengan tema belajar dan merancang pembelajaran yang efisien secara ekonomi seperti dengan memanfaatkan bahan sederhana; 2) Bekerjasama dengan orang tua murid dengan mengadakan pertemuan terbatas antara orang tua dan guru untuk membahas perkembangan siswa dalam belajar dari rumah; 3) Menggunakan sosial media untuk penyampaian informasi yang berkaitan dengan bahan ajar serta pengumpulan tugas murid dari para orang tua. 
Berdasarkan pada hasil penelitian, ada dua bentuk keterlibatan yang menyangkut peran orang tua, yaitu 1) Menjadi penuntun anak dalam belajar dari rumah. Peran ini harus dilakukan untuk meminimalkan kendala belajar pada anak usia dini; 2) Orang tua menjadi operator. Untuk efisiensi dan efektivitas pembelajaran, siswa perlu bantuan orang tua untuk menjembatani antara guru dan sisiwa. Orang tua menjadi penutur ulang apa yang disampaikan oleh guru. Dengan demikian kendala pada aspek ekonomi dapat ditekan dan memungkinkan terjadinya pembelajaran yang lebih efektif.

Beberapa saran dari penelitian ini adalah 1) Kerjasama orang tua dan sekolah perlu tetap dilaksanakan selama masa pandemi Covid-19 dengan terus berinovasi menyelenggarakan pembelajaran; 2) Upaya efisiensi pengeluaran biaya perlu terus diupayakan mengingat situasi pandemi Covid-19 telah berdampak juga pada sektor ekonomi; 3) Pembagian peran dan komunikasi antara guru dan orang tua perlu terus dioptimalkan sehingga meminimalkan masalah dalam belajar anak.

\section{Ucapan Terima Kasih}

Peneliti mengucapkan terima kasih kepada Pihak Pengelola TK Isa Almasih Pangkalan Bun yang telah membantu dalam memberikan informasi dan data yang relevan. Kepada tim peneliti yang telah terlibat mengumpulkan informasi dan mengola data yang terkumpul, serta melakukan kajian teoritis.

\section{DAFTAR REFERENSI}

Abidah, A., Hidaayatullaah, H. N., Simamora, R. M., Fehabutar, D., \& Mutakinati, L. (2020). The Impact of Covid-19 to Indonesian Education and Its Relation to the Philosophy of "Merdeka Belajar." Studies in Philosophy of Science and Education, 1(1), 38-49. https://doi.org/10.46627/sipose.v1i1.9

Cahyati, N., \& Kusumah, R. (2020). Peran Orang Tua Dalam Menerapkan Pembelajaran Di Rumah Saat Pandemi Covid 19. Jurnal Golden Age, 04(1), 152-159. Retrieved from http://www.ejournal.hamzanwadi.ac.id/index.php/jga/a rticle/view/2203

Diana, R. (2019). Prinsip Teologi Kristen Pendidikan Orang tua terhadap Anak di Era Revolusi Industri 4.0. BIA': Jurnal Teologi Dan Pendidikan Kristen Kontekstual, 2(1), 27-39. https://doi.org/10.34307/b.v2i1.79

Efendi, N. (2020). Implementasi Karakter Peduli Lingkungan di Sekolah Dasar Lolong Belanti Padang. Jurnal Komunikasi Pendidikan, 4(2), 62. https://doi.org/10.32585/jkp.v4i2.460

Ekayanti, N. W., \& Puspawati, D. A. (2020). Peran Orang Tua Dalam Mendidik Anak Ditengah Pandemi Covid-19. Prosiding Webinar Nasional Universitas Mahasaraswati $2020 . \quad$ Denpasar: Universitas Mahasaraswati Press. Retrieved from https://ejournal.unmas.ac.id/index.php/prosidingw ebinarwanita/article/view/1246

Handayani, L. (2020). Keuntungan, Kendala dan Solusi Pembelajaran Online Selama Pandemi Covid-19: Studi Ekploratif di SMPN 3 Bae Kudus. Journal Industrial Engineering \& Management Research (JIEMAR), 1(2), 2722-8878. https://doi.org/10.7777/jiemar.v1i2

Harper, P. (2020). How old do you have to be for Snapchat, Facebook, Instagram accounts? Social media age restrictions explained. Retrieved March 3, 2021, from The Sun 
website:

https://www.thesun.co.uk/tech/4136922/

age-restrictions-facebook-snapchat-

twitter-instagram/

Hayati, A. S. (2020). Peran Orang Tua dalam Meningkatkan Motivasi Belajar Anak Dengan Sistem Daring pada Masa Pandemi di Desa Depokrejo, Kebumen. TASYRI': JURNAL TARBIYAH-SYARI'AH ISLAMIYAH, 27(2), 23-32. Retrieved from http://ejournal.kopertais4.or.id/pantura/i ndex.php/tasyri/article/view/3552

Hutapea, R. H. (2020). Kreativitas Mengajar Guru Pendidikan Agama Kristen Di Masa Covid-19 [Teaching Creativity for Christian Religious Education Teachers in the Covid19 Period]. Didache: Journal of Christian Education, $1(1)$ https://doi.org/10.46445/djce.v1i1.287

Karnawati, K., \& Mardiharto, M. (2020). Sekolah Minggu Masa Pandemi Covid 19: Kendala, Solusi, Proyeksi. Didache: Journal of Christian Education, 1(1), 13-24. https://doi.org/10.46445/djce.v1i1.291

Lilawati, A. (2020). Peran Orang Tua dalam Mendukung Kegiatan Pembelajaran di Rumah pada Masa Pandemi. Jurnal Obsesi : Jurnal Pendidikan Anak Usia Dini, 5(1), 549. https://doi.org/10.31004/obsesi.v5i1.630

Mary, E. (2020). Implikasi Ulangan 5:16 Dalam Pendidikan Keluarga. Didache: Journal of Christian Education, 1(2), 141. https://doi.org/10.46445/djce.v1i2.331

Nainupu, A. M. Y., \& Emiyati, A. (2020). Kunci Keberhasilan Seorang Anak Dalam Pemaparan Alkitab. Didache: Journal of Christian Education, 1(2), 91. https://doi.org/10.46445/djce.v1i2.329

Nurjanah, N. (2007). Perilaku Seksual Pada Remaja Yang Berpacaran dan Remaja Yang Tidak Berpacaran. Universitas Islam Negeri Syarif Hidayatulah, Jakarta.

Onyema, E. M., Eucheria, N. C., Sen, F. A. S., Atonye, F. G., Sharma, A., \& Alsayed, A. O. (2020). Impact of Coronavirus Pandemic on Education. Journal of Education and Practice, 11(13), 108-121. https://doi.org/10.7176/jep/11-13-12
Purwanto, A., Pramono, R., Asbari, M., Hyun, C. C., Budi Santoso, P., Wijayanti, L. M., ... Santoso, P. B. (2020). Studi Eksploratif Dampak Pandemi COVID-19 Terhadap Proses Pembelajaran Online di Sekolah Dasar. EduPsyCouns: Journal of Education, Psychology and Counseling, 2(1), 1-12. Retrieved from https://ummaspul.ejournal.id/Edupsycouns/article/view/397

Rianingtias, H. (2017). Efektivitas Penggunaan Media Sosial Terhadap Capaian Pembelajaran Mahasiswa Fakultas IImu Pendidikan Universitas Negeri Malang (Universitas Negeri Malang; Vol. 0). Universitas Negeri Malang. Retrieved from http://karya-

ilmiah.um.ac.id/index.php/ASP/article/vie w/59246

Ritonga, Z. S. (2020). Analisis Implementasi Manajemen Berbasis Sekolah di Kecamatan Pantai. Jurnal Komunikasi Pendidikan, 4(1), 28. https://doi.org/10.32585/jkp.v4i1.432

Sanjaya, W. (2006). Strategi Pembelajaran Berorientasi Standar Proses Pendidikan. Jakarta: Kencana.

Septikasari, Z., \& Ayriza, Y. (2018). Strategi Integrasi Pendidikan Kebencanaan Dalam Optimalisasi Ketahanan Masyarakat Menghadapi Bencana Erupsi Gunung Merapi. Jurnal Ketahanan Nasional, 24(1), 47. https://doi.org/10.22146/jkn.33142

Subarto, S. (2017). Momentum Keluarga Mengembangkan Kemampuan Belajar Peserta Didik Di Tengah Wabah Pandemi Covid-19. Adalah: Buletin Hukum Dan Keadilan, 4(1). https://doi.org/10.15408/adalah.v4i1.153 83

Tafonao, T. (2018). Peranan Media Pembelajaran Dalam Meningkatkan Minat Belajar Siswa. Jurnal Komunikasi Pendidikan, 2(2), 103-114. https://doi.org/10.32585/jkp.v2i2.113

WhatsApp. (2018, June). Retrieved March 3, 2021, from Parent Zone website: https://parentzone.org.uk/article/whatsap $\mathrm{p}$ 